\title{
Molecular Biology Study on Plants Biofertilized with Water Hyacinth
}

\author{
Asmaa M. A. Nour', Reham M. Abd El-Azeem²*, Nashwa M. H. Rizk ${ }^{2}$ and Sabah F. El-Abd ${ }^{1}$ \\ ${ }^{1}$ Molecular Biology Department, Genetic Engineering and Biotechnology Research Institute, University \\ of Sadat City
}

2Environmental Biotechnology Department, Genetic Engineering and Biotechnology Research Institute, University of Sadat City

*Corresponding author: reham.abdelazeem@gebri.usc.edu.eg

\begin{abstract}
Despite water hyacinth (Eichhorniacrassipes) has become the world's worst invasive aquatic weed due to its rapid proliferation rate. It has demonstrated abilities to be used as a raw material in various useful applications. In this study, shredded dried water hyacinth was used as biofertilizer for tomato plants. Five concentrations of water hyacinth $(10,20,30,40$ and $50 \%)$ were added to soil consisted of three parts sand and one part peat moss. The 15 days tomato seedlings were collected where; Peroxidase enzyme activity and profiling of nine RAPD primers out of 10 were studied. The enzyme activity was increased in parallel with water hyacinth concentration in the soil. On the other hand the RAPD profiles showed no variations between all treatments and the control.
\end{abstract}

Key words: Water hyacinth- Biofertilizer- Tomato seedling- Peroxidase- RAPD

\section{INTRODUCTION}

Water hyacinth (Eichhorniacrassipes (Mart) Solms ), is a prolific free floating aquatic macrohpyte found in tropical and subtropical. It recognized to be very useful in domestic wastewater treatment ( Dinges 1976 ; Wolverton and McDonald, 1979).

Water hyacinth is a native of brazil, and is introduced to and is naturalized in many tropical countries. Eichhorniacrassipes (Mart) Solms belongs to taxonomic family Pontedericeae. Wild perennial herb is $30-40$ $\mathrm{cm}$ in length, with short stem and many long fibrous adventitious roots. Plants are floating, sometimes rooting.

Water hyacinth causes serious harms and has an adverse effect on water resources,fisheries, irrigation, drainage canals and public health. (Hussein, 1992, Obeid,
1984, Batanouny and EL- Fiky, 1984 and Sculthrope, 1967).

Water hyacinth is just beginning to be used for phytoremediation. This use came about for a few reasons, the first being that water hyacinth is so plentiful. People have been trying to remove the plant from many water ways. It has been discovered that water hyacinth's quest for nutrients can be turned in a more useful direction. Water hyacinth is already being used to clean up waste water in small scale sewage treatment plants. Phytoremediation used for removing heavy metals and other pollutants is a newly developed environmental protection technique. Extensive studies on freshwater resources decontamination revealed that some freshwater plants, among which is the water hyacinth growing prolific in wastewater, can 
efficiently accumulate heavy metals (Yahya, 1990; Vesk et al., 1999; Ali and Soltan, 1999; Soltan and Rashed, 2003; Tiwari et al., 2007). Water hyacinth also absorbs organic from the water column (Aoi and Hayashi, 1996).

In recent years, the plant has been used to treat a variety of wastewaters and to produce high protein cattle food, pulp, paper, fiber and biogas as energy source (Agency for International Development, 1976; Bates and hentges , 1976; kojima. 1986).

Woomeret al., (2000) indicated that Water hyacinth can be used both as a green manure on land or in the form of compost. Also, Water hyacinth is also used as a compost, vermicompost and green manure and is known to increase the productivity of various agricultural crops andvegetables(Sharma et al., 2016).

The aim of this search is to study the effect of using water hyacinth as biofertlilizer on tomato seedling plant using peroxidase enzyme activity and RAPD -PCR technique.

\section{MATERIALS AND METHODS}

\section{A - Plant material}

1- Water

hyacinth

Eichhorniacrassipes $(2 \mathrm{n}=32)$ were collected from fresh water near El- Mahalla city in Nile Delta , Egypt .

2- Tomato (Solanum lycopersicum) hybrid seed Agiad 16

$(2 n=24)$ were obtained from The Horticulture Research Institute (HRI). Dokki.Ggiza, Egypt

\section{B - Water hyacinth as biofertilizer}

Fresh water hyacinth were collected and dried under the direct sun for 1520 days till reducing almost all water content. After that the dried water hyacinth were shredded, then the shred was combined with soil where soil (3parts sand: 1 part peat moss)in five treatments beside the control.

Treatments were distributed in a randomized complete block design with four replicates. Each one $500 \mathrm{gm}$ as follow:

C: Control (100\%soil only).
$50 \%$ : $(50 \%$ shredded water hyacinth $+50 \%$ soil)

40\%: $(40 \%$ shredded water hyacinth $+60 \%$ soil)

30\%: (30\% shredded water hyacinth $+70 \%$ soil)

20\%: (20\% shredded water hyacinth $+80 \%$ soil)

10\%: $(10 \%$ shredded water hyacinth $+90 \%$ soil)

\section{C-Morphological variations of tomato}

Number of leaves /plant, stem length,plant length without roost, color of leaves andleaves shape (curl or straight), were recorded in 15 days tomato seedling in all treatments.

\section{D- Biochemical analysis}

Proxidase isozymes profile expressed in15 days tomato seedling was achieved in the present study. As conventional symbols in electrophoretic analysis, a pattern was first described in terms of Anodal $(A)$ and Cathodal $(\mathrm{C})$ zones according to their direction 
of mo-bility in the electrophoretic field. Each zone is assigned for a locus coding for a Peroxidase isozyme. Six different bulk for six plantssamples were examined for their isozyme patterns. A combination of agar-starch gel electropho-resis and enzyme activity attaining was used to screen for polymorphisms of pe-roxidase. The laboratory methods were performing according to Jonathan and Norman (1989).

\section{E- DNA extraction}

Genomic DNA was extracted using CTAB method(1\% CTAB using ). (Doyle and Doyle (1987)). DNA was quantified by Gene quant at absorbance of 260/280 $\mathrm{nm}$. The quality was further checked on $0.1 .5 \%$ agarose gel.

\section{F- RAPD analysis}

Random amplified polymorphic DNA (RAPD), has been developed, in which DNA is amplified using ten (10 mer) RAPD primers (Williams et al., 1990). The PCR Operon primers used for RAPDs are listed in Table (1). These pri-mers were selected from the Operon kits (Operon Technologies Inc., Alabameda
CA). RAPD-PCR analysis was performed according to the method of Williameset al. (1990). The polymerase chain reaction mixture $(25 \mu \mathrm{l})$ consisted of $0.8 \mathrm{U}$ of Taq DNA polymerase; 25 pmol dNTPs; 25 pmol of primer and $100 \mathrm{ng}$ of genomic DNA. PCR amplification was performed in a Biometra T1 gradient thermalcycler for 40 cycles after initial denaturation for $3 \mathrm{~min}$ at $94^{\circ} \mathrm{C}$. Each cycle consisted of denaturation at $94^{\circ} \mathrm{C}$ for $1 \mathrm{~min}$; annealing at $36^{\circ} \mathrm{C}$ for $1 \mathrm{~min}$; extension at $72^{\circ} \mathrm{C}$ for $2 \mathrm{~min}$ and final extension at $72^{\circ} \mathrm{C}$ for $10 \mathrm{~min}$ (Solimanet al., 2003). Amplification products were separated on $1.5 \%$ agarose gels at 100 volts for $1.30 \mathrm{hrs}$ with $1 \times$ TBE buffer. To detect ethidium bromide/DNA complex, agarose gels were examined on ultraviolet transilluminator and photo-graphed. Using 100 bp DNA ladder (Sizer 1000 bp plus DNA maker, intron biotechnology), the lengths of the different DNA fragments were determined. The reproducible DNA fragments from two runs were scored for their presence (1) or absence (0) for each genome.

Table (1): The nucleotide sequences of primers used for RAPD analysis.

\begin{tabular}{|c|c|c|c|}
\hline Primer code & Sequence $\left(5^{\prime}\right.$ - $^{\prime}$ ) & Primer code & Sequence $\left(5^{\circ}\right.$-3 $\left.^{`}\right)$ \\
\hline 1- OPA-05 & AGG GGT CTT G & 2- OPA-01 & CAG GCC CTT C \\
\hline 3- OPA-10 & GTG ATC GCA G & 4- OPD-03 & GTC GCC GTC A \\
\hline 5- OPH-03 & AGA CGT CCA C & 6- OPO-02 & ACG TAG CGT C \\
\hline 7- OPR-01 & $\begin{array}{l}\text { CTT CCG CAG T } \\
\text { (TGCGGGTCCT) }\end{array}$ & 8- OPO-03 & CTG TTG CTA C \\
\hline 9- OPO-05 & CCC AGT CAC T & 10-OPR-05 & GAC CTA GTG G \\
\hline
\end{tabular}

\section{RESULTS}




\section{A- Morphological variations in tomato} seedling

Morphological variation betweens 15 days tomato seedling (Table 2) showed low significant variationsbetween the five treatments of water hyacinth as biofertilizer and the control (zero \% water hyacinth).

Number ofleaves in the control was three leaves as in 50\%, 30\%,10\% treatmentswhile in 40\%, 20\% treatment two leaves only were observed.
The plantlength, withoutroots showed low significant variations in all studied treatments. It ranged from 6.0 to $10.0 \mathrm{~cm}$ with the mean of $8.0 \mathrm{~cm}$

The length of stem showed range from $5.0 \mathrm{~cm}$ to $8.0 \mathrm{~cm}$ with mean of $6.5 \mathrm{~cm}$ in the studied treatments.

All plants in the five treatments of water hyacinth show green color of leaves. And the shapes of all leaves arestraight as in control.

Table (2): morphological variation of tomato in different concentration of water hyacinth as fertilizer

\begin{tabular}{|l|c|c|c|c|c|}
\hline Treatments & $\begin{array}{c}\text { No. of } \\
\text { leaves }\end{array}$ & $\begin{array}{c}\text { Length of stem } \\
\mathbf{C m}\end{array}$ & $\begin{array}{c}\text { Length of plant } \\
\text { without root in } \mathbf{C m}\end{array}$ & $\begin{array}{c}\text { Color of } \\
\text { leaves }\end{array}$ & $\begin{array}{c}\text { Shape of } \\
\text { leaves }\end{array}$ \\
\hline $\mathbf{5 0} \%$ & $\mathbf{3}$ & $5.5-6.0$ & $6.5-7.5$ & Green & Straight \\
\hline $\mathbf{4 0} \%$ & $\mathbf{2}$ & 5.0 & $6.0-7.0$ & Green & Straight \\
\hline $\mathbf{3 0} \%$ & $\mathbf{3}$ & 6.5 & $7.5-8.0$ & Green & Straight \\
\hline $\mathbf{2 0} \%$ & $\mathbf{2}$ & 5.0 & $6.5-7.5$ & Green & Straight \\
\hline $\mathbf{1 0} \%$ & $\mathbf{3}$ & $7.5-8.0$ & $9.0-9.5$ & Green & Straight \\
\hline Control & $\mathbf{3}$ & $8.0-8.5$ & $9.5-10.0$ & Green & Straight \\
\hline Mean & & 6.5 & 8 & & \\
\hline
\end{tabular}

\section{Biochemical genetic analysis}

The zymogram and photograph showing mobility pattern of peroxidase isozymes are illustrated in figuers (1 and 2). It can be conducted from these data that,the peroxidase patterns in the control and the five treatments show two kind of patterns (Px.1a , Px.2a). The Two out of detected iso-enzyme bands shifted, as a rule, to the cathode only and there is no bands shifted to anode. Bands show high intensity in 50\% Conc. and decreased till the control.

This result indicating that the enzyme activity is increasing in parallel with the water hyacinth concentration in the soil.
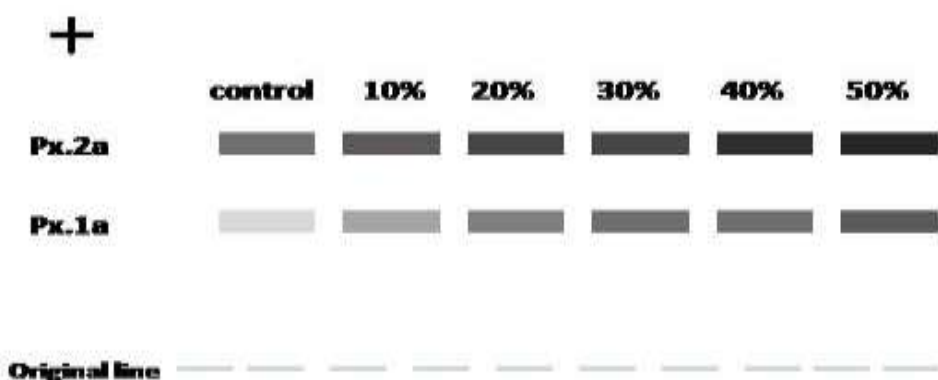
Fig. (1): Zymograms showing electrophoretic profiles of Peroxidase isozyme of 15 days seedling tomato plants in five concentrations of water hyacinth as biofertilizer

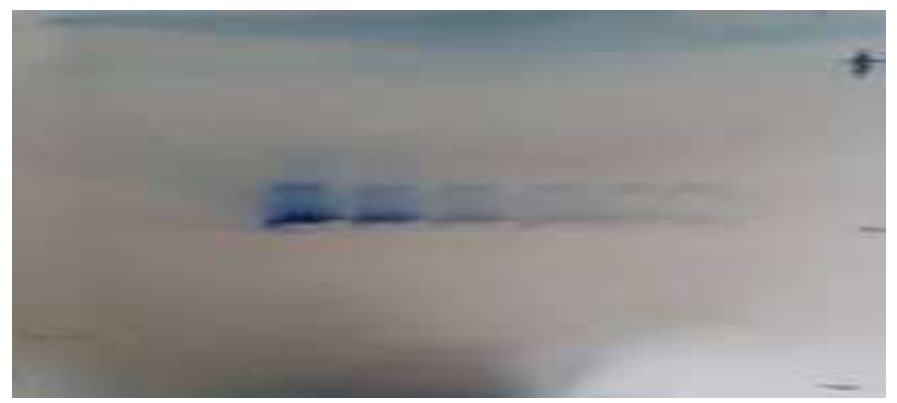

Fig. (2): photograph showing electrophoretic profiles of Peroxidase isozyme of 15 days seedling tomato plants in five concentrations of water hyacinth as biofertilizer

\section{$B-\quad R A P D-P C R$ profiling}

Ten RAPD primers were used to detect the effect of using water hyacinth as biofertilizer on 15 days tomato seedling DNA. Nine primers out of ten gave results. As shown in Table (1) and Fig. (1), the number of reproducible bands/primer varied between 2 for primersOPA-01 OPA-10, and OPO-02 and 10 for primer OPO-05with a total of 34 bands with an average of 3.7 bands per primer.

All the studied primers showed no polymorphism and had no differences from the control.

The highest band number (10) which produced primer OPO-05 ranged from 263 to1,208 bp, while the five band resulted by primer OPR-1 ranged from325 to 939bp (Table 1)The results of primer $\mathrm{OPH}-03$ are illustrated in Table (1). It showed a maximum of 4 amplification fragments with size ranged from264 to $1,097 \mathrm{bp}$. For primer OPO-03,

Table :(3). Number of amplified fragments and their molecular size based on RAPD analysis

\begin{tabular}{|c|c|c|}
\hline Primer & No. of bands & Msize. range bp \\
\hline OPO-05 & 10 & $263-1,208$ \\
\hline OPR-01 & 5 & $325--939$ \\
\hline OPH-03 & 4 & $264-1,097$ \\
\hline OPO-03 & 3 & $287-745$ \\
\hline OPA-05 & 3 & $303-666$ \\
\hline OPD-03 & 3 & $254-490$ \\
\hline OPA-10 & 2 & $301-454$ \\
\hline
\end{tabular}




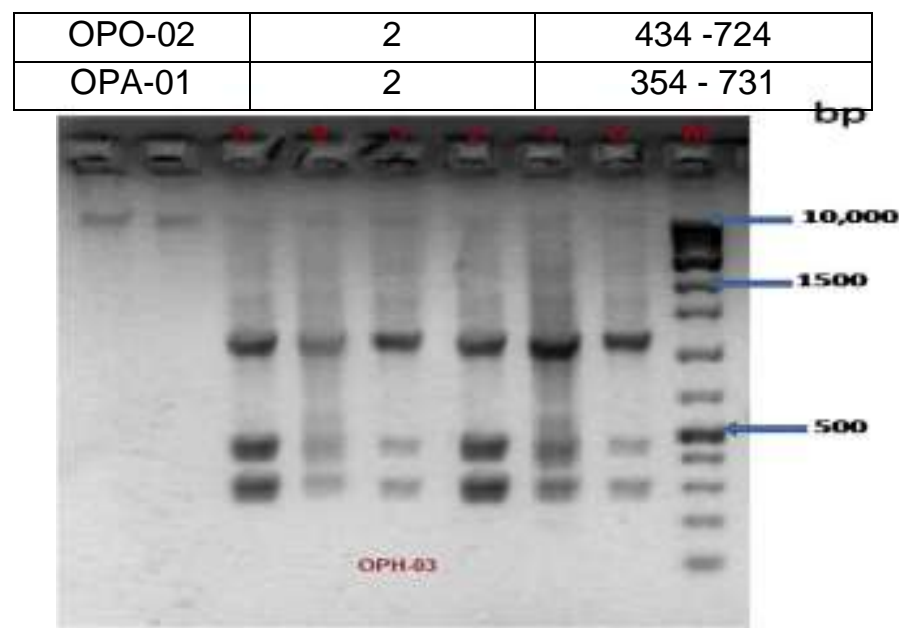

Fig. (3) An example of RAPD primer OPH-03 showing no polymorphism between used concentration of water hyacinth $(\mathrm{WH})$ on 15 day tomato seedling (c=0\% WH, $1=10 \% \mathrm{WH}, 2=20 \% \mathrm{WH}, 3=30 \% \mathrm{WH}$, $4=40 \% \mathrm{WH}$ and $5=50 \% \mathrm{WH}$ )

\section{DISCUSSION}

In this search we investigated the effect of shredded dried water hyacinth as biofertilizer on 15 days tomato seedling. Five of concentrations of water hyacinth were used beside the control which contained 3parts sand: 1 part peat moss.

The result showed that peroxidase activity was increased with increasing the concentration of water hyacinth in the soil. Meanwhile, the RAPD profiles showed no variations between the control and all the treatments. Indicate that there was no effect of using water hyacinth as biofertilizer on 15 days tomato seedling DNA.

Blessy, and .Prabha(2014) indicated that water hyacinth improves structural stability of the soil, thereby preventing soil erosion and enhances the quality of grains/ fruits. Also, Widjajantoet al. $(2001,2002)$ reported the benefit of using residues such as water hyacinth where it produces pathogen free rich compost which increases soil fertility, thereby improves the fertility of soil.

Phuaet al.,(2012) indicated that biofertigation could increase the growth of tomato seedlings. On the same trend,Dinu et al., (2015) showed that the treatment of the tomato plants during vegetation with biofertilizers.

Despite many reference indicated that water hyacinth accumulate heavy metals, (Muramoto and Oki, 1983; Zhu et al., 1999; Soltan and Rashed, 2003; Tiwari et al., 2007 and Sharma et al., 2016) - there was changing in the $d$ of tomato 15 day seedling. this indicates that water hyacinth is safe on the plants as a biofertilizers and cause no harms for the plants.

\section{CONCLUSIONS}

From this study and in agreement with (Murugesan et al., 1994), the aquatic weed water hyacinth (Eichhorniacrassipes(Mart.) Solms.), besides being a nuisance in nutrient- enriched public water bodies, is a low-cost alternative source of biofertilizer. Where it showed a good peroxidase enzyme activity and did not cause any alteration in the DNA of 
the tomato which was biofertilized with water

hyacinth.

\section{REFERENCE}

Agency for International Development (1976). Making Aquatic Weeds Useful, Some Perspectives for Developing Countries. National Tech. Inf. Ser. Washington D.C., No. PB 161-255.

Ali, M.M.andSoltan, M.E. (1999). Heavy metals in aquatic macrophytes, water and hydrosoils from the river Nile.Egypt. J. Union Arab. Biol., 9:99-115.

Barnabas, A.D. (1996). Casparian band like structures in the root hypodermis of some aquatic angiosperms. Aquatic.Bot., 55:217-225.

Bates, R.P.andHentges, J.F. (1976). Aquatic weeds-eradicate or cultivate. Econ. Bot., 30:39-50.

Blessy, K., and .Prabha L. (2014). Application of water hyacinth vermicompost on the growth of Capsicum annum. International Journal of Pharma Sciences and Research, 5(5): 198- 203.

Dinges, R. (1976). Water hyacinth culture for wastewatertreatment. Texas Department of Health Resources, Austin,Texas, USA.

Dinu, M., M. G. Dumitru and R. Soare (2015).. The effect of some biofertilizers on the biochemical components of the tomato plants and fruits. Bulg. J. Agric. Sci., 21: 9981004.

Doyle, J. J. and J. L. Doyle (1987). A rap-id isolation procedure for small quantities of fresh leaf tissue. Phytochem. Bul., 19: 1115.

Hussein, A.M. (1992). Industrial utilization of water hyacinth as complement to mechanical control. Proc. National Sympo. On

Water Hyacinth, Assiut Univ. pp. 103- 117.

Jonathan, F. W. and F. W. Norman

(1989). Isozymes in plant biology: Visualization and interpretation of plant isozymes. Chapter 1: 5-45.

Kojima, T. (1986). Generation of methane gas from water hyacinth (Eichhorniacrassipes), production of methane gas from combination of water hyacinth and fowl droppings. Bulletin of the Faculty of Agriculture, Saga University, Japan, 61:1-8.

Muramoto, S. and Y. Oki, 1983. Removal of some heavy metals from polluted water by water hyacinth (Eichhorniacrassipes). Bull. Environ. Contam. Toxicol., 30: 170-177.

Phua, C.K.H., Abdul Wahid, A.N. and Abdul Rahim, K. (2012). Assessment of multifunctional biofertilizers on tomato plants cultivated under a fertigation system. Research and Development

Seminar 2012; Bangi (Malaysia); 2628 Sep. http://www.iaea.org/inis/collection/NCLCollectio nStore/_Public/44/096/44096844.pdf

Sharma, A., Aggarwal,N. K., Saini, A. and A. Yadav (2016). Beyond biocontrol: water hyacinth-opportunities and challenges. J. Environ. Sci. Technol., 9 (1): 26-48.

Soliman, S. S., A. A. Bahy and M. M. Mo-hamed (2003). Genetic compari-sons of Egyptian date palm cultivars (Phoenix dactylifera L.) by RAPD-PCR. African Journal of Biotechnology, 2: 86-86.

Soltan, M.E. and M.N. Rashed, 2003. Laboratory study on the survival of water hyacinth under several conditions of heavy 
metal concentrations. Adv. Environ. Res., 7: 321-334.

Tiwari, S., S. Dixit, N. Verma, 2007. An effective means of biofiltration of heavy metal contaminated water bodies using aquatic weed Eichhorniacrassipes. Environ. Monit. Assess., 129: 253-256.

Widjajanto, D. W., Matsushila, K., Honmura, T., Miyanch, N. (2001). Studies on the Release of $\mathrm{N}$ from Water Hyacinth Incorporated into Soil-Crop Systems Using 15N-labeling Techniques. Part J. Biol. Sci. 4: 10754-1077. 30. Widjajanto, D. W., Honmura, T., Miyauchi, N., (2002). Nitrogen Release from Green Manure of Water Hyacinth in Rice Cropping Systems. Pak. J. Biol. Sci. 5:740743.
Williams, J. K., A. R. Kubelik, K. J. Livak, J. A. Rafalski and S. V. Tingey (1990). DNA polymor-phisms amplified by arbitrary primers are useful as genetic markers. Nucleic Acids Res., 18: 6531-6535.

Woomer, P.L., R. Muzira, D. Bwamiki, D. Mutetikka, A. Amoding and M.A. Bekunda, (2000). Biological management of water hyacinth waste in Uganda. Biol. Agri. Hortic., 17: 181-196.

Zhu, Y.L., A.M. Zayed, J.H. Qian, M. de Souza and N. Terry, 1999. Phytoaccumulation of trace elements by wetland plants: II. Water hyacinth. J. Environ. Qual., 28: 339-344. 